\title{
EXPLORING STRATEGIC CHOICES OF AIRLINES: A STUDY IN TURKISH AIR TRANSPORT INDUSTRY
}

\author{
Hüseyin Önder Aldemir ${ }^{1 *}$, Ferhan Kuyucak Şengür ${ }^{2}$, and İbrahim Cemil Ulukan ${ }^{3}$ \\ ${ }^{1}$ Department of Aviation Management, Faculty of Aviation and Aeronautical Sciences, \\ Ozyegin University, Istanbul, Turkey \\ ${ }^{2}$ Department of Aviation Management, Faculty of Aeronautics and Astronautics, \\ Eskisehir Technical University, Iki Eylul Campus, Eskisehir, Turkey \\ ${ }^{3}$ Faculty of Economics and Administrative Sciences, Anadolu University, \\ Eskisehir, Turkey
}

*Corresponding author: onder.aldemir@ozyegin.edu.tr

Published online: 1 December 2021

To cite this article: Aldemir, H. O., Sengür, F. K., \& Ulukan, I. C. (2021). Exploring strategic choices of airlines: A study in Turkish air transport industry. Asian Academy of Management Journal, 26(2), 1-26. https://doi.org/10.21315/aamj2021.26.2.1

To link to this article: https://doi.org/10.21315/aamj2021.26.2.1

\begin{abstract}
Inter-firm competition in the field of aviation, which accelerates through liberalisation and globalisation trends, has been investigated by numerous studies in the post-deregulation era; however, it has not been adequately addressed in Turkish aviation market. The aim of this study is to unveil the business strategies and strategic typologies of Turkish passenger carriers, as well as the degree of involvement of firms in the strategic planning process, the current outlook, and the competitive structure of the Turkish passenger air transport industry. The research is designed in a way to collect data through interviews with senior executives of the airlines. In terms of findings, the study concludes that five scheduled airlines and three charter airlines have attempted to implement more than one generic strategy at the same time as an "integrated cost and differentiation strategy," with the primary strategy being cost leadership. Moreover, the passenger carriers in question displayed the features of "analysers-defenders" mainly linked to the competitive typology viewpoint. This study is believed to lead to a deeper understanding of potential explanations why companies have made specific strategic choices regarding generic strategies and strategic approaches. Regulators, individual companies operating in the aviation industry and prospective companies, investors, etc. can use the results of the study to regulate the
\end{abstract}

(C) Asian Academy of Management and Penerbit Universiti Sains Malaysia, 2021. This work is licensed under the terms of the Creative Commons Attribution (CC BY) (http://creativecommons. org/licenses/by/4.0/). 
market, better understand their competitors, set their priorities and plans, evaluate, and assess the market.

Keywords: airline competition, air transport, competitive strategies, Miles and Snow typology, Porter's generic strategies, hybrid strategies

\section{INTRODUCTION}

As one of the most critical sectors for a robust economy, the airline industry was historically dominated by flag carriers and government-owned airlines. Following the deregulation and liberalisation trends, worldwide competition has started to become the agenda of the airline industry. According to the International Civil Aviation Organization (ICAO) in 2018, the total number of passengers carried on scheduled airlines of Member States rose to 4.3 billion in 2018 , which is $6.4 \%$ higher than the previous year with an operating profit of more than USD50 billion (ICAO, 2017). In addition to its vital role in the economy, air transport has already an important role in the tourism industry. Transport infrastructure of a destination is a significant determinant of tourism inflows into a destination (Khadaroo \& Seetanah 2008). According to the International Air Transport Association (IATA) in the year $2017,52 \%$ of international tourists worldwide travelled by air (IATA, 2018a).

In aviation industry, the airlines have to develop adaptive and strategic responses in competitive environment to survive and prosper (Goll et al., 2006). The content of strategy focuses mainly on the results of strategic decisions (Morgan \& Strong, 2003) and the organisation uses strategy to deal with changing environments (Chaffee, 1985). Businesses formulate and implement competitive strategies to survive and to excel in the competitive environment. Strategic orientation refers to the way an organisation uses strategy to adapt to and/or change aspects of its environment to achieve a more favourable alignment and has been described variously as a strategic choice, strategic direction, strategic fit, and strategic predisposition (Manu \& Sriram, 1996). Beginning from the 1970s, systematic work in management literature started to identify behaviours or common factors in how companies compete to propose strategic orientations or typologies of generic strategies to operationalise the notion of strategic posture (Avci et al., 2011).

The well-known approaches of strategic management to create competitive advantage are Porter's generic strategies, Miles and Snow's typology, resourcebased view, outpacing approach, and blue ocean strategies. This study focuses on Miles and Snow's typology and Porter's generic strategies in the Turkish 
airline market. Miles and Snow (1978) argued that business firms develop similar solutions as they deal with entrepreneurial, engineering (or operational), and administrative problems and proposed a typology indicating four strategic types of organisations: defenders, prospectors, analysers, and reactors. Porter (1980, p. 34) defines competitive strategy as "taking offensive or defensive actions to create a defendable position in an industry, to cope successfully with the five competitive forces and thereby yield a superior return on investment for the firm." He proposed three different "generic" strategies by which an organisation could achieve competitive advantage: overall cost leadership, differentiation, and focus. Both the Miles and Snow typology and the generic framework of Porter were later tested in various studies in different cultures, industries, and contexts, especially in the Western countries; but there has been limited application of these frameworks in emerging nations (Zahra \& Pearce, 1990; Jusoh \& Parnell, 2008; Avci et al., 2011).

Inter-firm competition in the air transport industry, which increases its speed and impacts through liberalisation and globalisation trends, has not been adequately addressed within the context of emerging markets. A qualitative study was designed as an implementation of Miles and Snow's typology and Porter's generic strategies to examine strategic orientations of airlines in Turkey. The analysis included eight airlines (all private passenger airlines competing in the market during the research) and revealed competitive typologies of airlines and the competitive structure of the Turkish airline industry. The paper aims to contribute to a better understanding of competitive strategies in Turkey's airline industry by two means. Firstly, it will help the airlines understand the market, strategy making behaviours of others and also their own. Secondly, in a macro viewpoint, it will give insights to the authorities, regulators, investors, and all other stakeholders in the industry. A better understanding of strategic typologies of airlines in the Turkish market and competitive structure of the industry will contribute to cope with inefficiencies in the market and establish a real competitive environment.

\section{THEORETICAL BACKGROUND}

The strategic management literature outlines several typologies to understand the strategic orientations of the firms. Miles and Snow's typology (1978) is one of the most notable of the strategic orientation typologies. Miles et al. (1978) referred strategic orientation as the firm's specific patterns of behaviour, which are a set of consistent responses to the environment. Miles and Snow (1978) drew the theoretical framework of this adaptation process called "adaptive 
cycle." They identified four strategic orientations for the organisations' particular patterns of behaviours: defenders, prospectors, analysers, and reactors. Defenders maintain a secure niche in a relatively stable product or service area and have a centralised structure (Miles et al., 1978). They are unwilling to explore new markets, avoid risks, and follow successful rivals (Brunk, 2003). Since prospectors seek novelties and always try to be innovative and the first in the market, research and development is a crucial function for prospectors. They face risks in the environment and act proactively; thus, prospectors give rapid responses to the environment and the rivals. They apply a decentralised structure and are willing to change (Miles et al., 1978; Allen \& Helms, 2006). Analysers are hybrid of defenders and prospectors. They mostly monitor the actions of innovative competitors and are not at the forefront. They try to maintain stable, limited line of products or services. Reactors do not have a consistent product-market orientation and do not have a vision in the market; as a result, they are not successful (Miles et al., 1978; Moore, 2005).

Some researchers (Hambrick, 1983; Smith et al., 1986; McDaniel \& Kolari, 1987; Zahra \& Pearce, 1990; Parnell \& Wright, 1993) studied the dynamics and conceptual structure of Miles and Snow's strategy, while some of them (Slater \& Narver, 1993; Gibcus \& Kemp, 2003; DeSarbo et al., 2005; Obel \& Gurkov, 2013; Martins et al., 2014) interrogated, reviewed, tested, extended, and validated the theoretical fundamentals of Miles and Snow's typology. Zahra and Pearce (1990) based on Miles and Snow's typology emphasised three main premises. The first is that successful organisations have developed a systematic and identifiable approach to environmental adaptation over time. The typology clarified the adaptive cycle that represents general physiology of organisational behaviour and provides a means of conceptualising the significant elements of adaptation and of visualising the relationships among them. The second premise is the existence of four identifiable strategic orientations within the industry. The main difference among these strategies is the rate of change of the organisational domain. The third premise of typology is that the defender, prospector, and analyser strategies can lead to effective performance if appropriately applied. The majority depends on the internal consistency among the three components of the adaptive cycle. Each type emphasises different functions in order to produce a set of sustainable, distinctive competencies. The reactors lack consistent strategy. As a result, the typology proposes that defenders, prospectors, and analysers outperform the non-adaptive reactors.

This typology has been applied to miscellaneous industries and sectors by many researchers such as hospital industry (Beekun \& Ginn, 1993), biotechnology industry (Weisenfeld-Schenk, 1994), banking sector (James \& Hatten, 1995), 
retail industry (Moore, 2005), engineering and electronics manufacturers (O'Regan \& Ghobadian, 2006), tourism industry (Avci et al., 2011), hospitality industry (Köseoglu et al., 2013), freight forwarding companies (Karingithi et al., 2020), semiconductor industry (Lin et al., 2020), petrochemical projects (Hani et al., 2020), gelatine industry (Bustamam \& Pech, 2016), and cement and other minerals sector (Anwar et al., 2016) to demonstrate the competitive strategies of the different enterprises in the industry in practice.

In the context of small businesses, Gimenez (1999) concluded that there was a strong support for suggesting all four different generic strategies in various environmental conditions. He put forward that while prospector strategies mostly dominate in dynamic environments, defenders have become dominant in more stable industries. Anwar et al. (2016) provided an updated review of relevant literature and summarised the measures and relationships used for operationalisation of the strategy-performance by empirical research using seven-year financial data of cement and other minerals sector in Pakistan. They classified the firms according to the Miles and Snow's typology for four years and demonstrated the strategy transition yearly. They also concluded that most of the firms were following analyser strategy (48\%), followed by defender-analyser (hybrid), and reactors (19\%). Cassol et al. (2019) analysed the strategic behaviours of micro and small-sized enterprises from different sectors in the perception of managers by applying Miles and Snow's typology in Brazil. As a result of this research, while the predominant strategic behaviour of the companies was analyser, the reactor behaviour was least presented. Hawrysz (2020) searched the impact of the Miles and Snow's strategic orientation on e-administration effects in Poland. He concluded that the defender orientation was positively associated with the effects of e-administration.

Some authors claimed that strategic choice is complex rather than simple and identified hybrid strategy types that deviate from the four-strategy types defined by Miles and Snow (DeSarbo et al., 2005; Helmig et al., 2014). Anwar and Hasnu (2017) studied on the Pakistani joint stock firms from 12 industries. The result showed that Pakistan firms practiced hybrid and reactor strategies more than pure ones and demonstrated defending and analysing strategies perform better than the prospecting strategies.

Studies testing Miles and Snow's typology in the airline industry is quite limited. Bahaee (1992) tested the typology in the regional airline industry and found that the four Miles and Snow strategic types would be present in the United States (US) regional airline industry. This research proposed that congruence between strategic orientation and decision-making comprehensiveness of the strategic 
planning process is a greater determinant of firm performance to planning alone. This empirical study was carried out in the US regional airline industry since regional airlines comprise a relatively homogeneous set of organisations that fit the definition of small, entrepreneurial ventures. A significant relationship was found between both high and medium levels of congruence and performance. Of these regional airlines in the US, the results demonstrated that there were 19 defenders, 9 prospectors, 24 analysers, and 30 reactors.

Porter (1985) suggests that firms should follow one of three generic strategies for achieving above-average performance in an industry: (1) cost leadership: producing goods and services at the lowest cost and selling them at the market price, (2) differentiation: producing distinct goods and services, such as in design, function, or use, etc., and (3) focus: focusing solely on the specific needs of market niches. The focus strategy has two variants, cost focus and differentiation focus. The cost leadership and differentiation strategies seek competitive advantage in a broad range of industry segments, while focus strategies aim at cost advantage (cost focus) or differentiation (differentiation focus) in a narrow segment. Following various strategies for the same products or services simultaneously may put firms into danger, and this is called as "stuck in the middle" (Porter, 1985). Cost leadership needs a high market share to achieve economies of scale while a successful differentiation strategy requires a clear understanding and perceiving of customer needs. Focus strategies concentrate on serving a particular market niche, which may be defined geographically, by segment of product line, or by type of customer (Porter, 1985; Kling \& Smith, 1995). Stuck-in-the-middle firms lack a clearly defined strategic position. They take a defensive position and merely react to the environment (Porter, 1985; Johnson et al., 1989).

Porter (1985) warns that the firms applying hybrid position will fail to achieve an advantage and end up with competing at a disadvantageous position compared with those that have chosen a pure generic strategy. However, some authors offer a fifth option as "integrated cost leadership and differentiation strategy" (Coulter, 2002; Hitt et al., 2003) in which an organisation develops a competitive advantage by simultaneously achieving low costs and high levels of differentiation (Coulter, 2002; Dostaler \& Flouris, 2006). Cronshaw et al. (1994) concluded that successfully combined cost leadership and differentiation would be better than applying pure strategies. Manev et al. (2015) examined the impact of pure versus hybrid competitive strategies on competitive performance in transition economies in the context of Bulgaria. As a conclusion of their research, firms deviating from pure cost leadership or differentiation by achieving a balance on both dimensions demonstrated superior performance. Gabrielsson et al. (2016) searched multinational corporations with the perspective of the resource-based 
view to examine the attainment of a hybrid competitive strategy. They indicated how high technology firms that operate in an uncertain and dynamic environment could realise a hybrid competitive strategy that leads to superior financial performance.

Segev (1989) put forward the similarities of two typologies. He matched the prospectors with differentiation and differentiation-focus as high proactive strategies, defenders with cost-leadership and cost-focus which are low risk strategies. He also found analysers closer to the focus strategies while matching the reactors with "stuck in the middle." While the Porter model finds many application fields in miscellaneous industries, it was also applied to airline industries in several countries. Johnson et al. (1989) presented the average earnings data of the airlines operating in the US for the regulatory and deregulatory periods by utilising Porter's strategic classifications. As a result of this study, they found that business strategy may serve as an essential variable in determining wages. Kling and Smith (1995) identified strategic groups among the nine major US passenger airlines utilising the framework of Porter's generic strategy typology. They found that five airlines appeared to be successfully following one of the three generic strategies and therefore enjoyed better competitive positions in the industry and superior profitability. Goll et al. (2006) found a significant relationship between business strategy and firm performance in the US airline industry. Dostaler and Flouris (2006) tried to develop a conceptual framework that could be used to explore the extent to which airline companies successfully follow the integrated cost leadership-differentiation strategy, and how they manage to resolve the tradeoff between low-cost and differentiation. They concluded that many traditional airlines, having low-cost subsidiaries to compete with low-cost carriers, might fail and find themselves with "stuck in the middle" strategy. Heracleous and Wirtz (2009) searched Singapore Airlines' achievement of its outstanding performance and sustainability of its competitive advantage through effectively implementing a dual strategy as differentiation through service excellence and innovation, together with simultaneous cost leadership in its peer group. Omwoyo (2016) demonstrated the effects of generic strategies on the competitive advantage of firms in Kenya's airline industry. Lauer (2019) discussed the validity of Porter's generic strategies, the outpacing concept and blue ocean strategies by using cases from the airline industry and grocery retail sector. He concluded that while generic and blue ocean strategies neglect dynamics, the outpacing concept is still confined by Porter's strategies.

In Turkey, a few studies examined the different dimensions of competition in the industry. Torlak et al. (2011) analysed the competition of Turkish domestic airline industry by examining nine criteria (advertising, product quality, price 
competitiveness, customer loyalty, market share, customer service, e-commerce, management experience, and branding) by employing fuzzy TOPSIS method and made a comparative evaluation among air carriers. Examining the competitive actions undertaken by the firms operating in the airline industry in Turkey, Sonmez and Eroglu (2017) categorised the competitive actions and found the competition in the industry is intensive. Our study aims to clarify another dimension of interfirm competition in the Turkish airline industry by exploring the strategic choices of the airlines.

\section{The Current Outlook of the Turkish Air Transport Market}

Turkey is an emerging economy with an advantageous geographical location between Europe and Asia. Although air transportation in Turkey has a relatively long history, especially the growth of domestic passenger transportation has started from the 2000s with deregulation efforts and government incentives, thus, competition between airlines became to the agenda. As annual data of 2018, approximately 211 million passengers have flown in Turkey (GDSAO, 2019). Carrying $73.5 \%$ of arriving visitors in Turkey, contribution of air transportation is overwhelmingly very high in the tourism industry (Hotel Association of Turkey, 2019). As an emerging economy with a per capita income of USD9,140 and with a population of 82.6 million (The World Bank, 2019), Turkey has one of the fastest-growing air transportation markets. According to IATA projections, by 2036, Turkey will be the fifth fastest-growing market after China, the US, India, and Indonesia in the world (IATA, 2017). The passenger traffic in Turkey for the past 15 years can be seen in Table 1 .

As seen in Table 1, the domestic passenger traffic increased approximately 12 times, while the international passenger traffic soared up 3.3 times since the 2003 deregulation. In total, Turkey's passenger traffic increased around 5.6 times with only an exception of the year 2016 due to crises in tourism. The industry has witnessed a quick recovery and increase rate of passenger traffic has reached double-digit numbers in 2017, which is above the world average. The country's geographical location creates a natural advantage for a global flight network which allows growth for not only origin-destination air traffic but also regional and global transfer traffic for the competitiveness of the airline industry (Sengür \& Ustaömer, 2019). All these factors not only led a continuous growth both in passenger and cargo traffic but also contributed to the construction of competition in the industry. Especially after the 2003 domestic deregulation, the industry has witnessed competitive interaction between airlines and strategic choices of the firms started to become more distinctive. 
Table 1

Passenger traffic after 2003 deregulation in Turkey

\begin{tabular}{rrrccc}
\hline Years & \multicolumn{1}{c}{ Domestic } & International & Transit & Total & Change rate (\%) \\
\hline 2003 & 9.147 .439 & 25.296 .216 & - & 34.443 .655 & - \\
2004 & 14.460 .864 & 30.596 .507 & - & 45.057 .371 & $\mathbf{2 3 . 6}$ \\
2005 & 20.529 .469 & 35.042 .957 & 547.046 & 56.119 .472 & 19.7 \\
2006 & 28.774 .857 & 32.880 .802 & 616.217 & 62.271 .876 & 9.9 \\
2007 & 31.949 .341 & 38.347 .191 & 418.731 & 70.715 .263 & 11.9 \\
2008 & 35.832 .776 & 43.605 .513 & 449.091 & 79.887 .380 & 11.5 \\
2009 & 41.226 .959 & 44.281 .549 & 492.835 & 86.001 .343 & 7.1 \\
2010 & 50.575 .426 & 52.224 .966 & 736.121 & 103.536 .513 & 16.9 \\
2011 & 58.258 .324 & 59.362 .145 & 671.531 & 118.292 .000 & 12.5 \\
2012 & 64.721 .316 & 65.630 .304 & 677.896 & 131.029 .516 & 10.8 \\
2013 & 76.148 .526 & 73.281 .895 & 565.447 & 149.995 .868 & 14.5 \\
2014 & 85.416 .166 & 80.304 .068 & 461.105 & 166.181 .339 & 10.8 \\
2015 & 97.041 .210 & 84.033 .321 & 362.473 & 181.437 .004 & 9.2 \\
$\mathbf{2 0 1 6}$ & $\mathbf{1 0 2 . 4 9 9 . 3 5 8}$ & $\mathbf{7 1 . 2 4 4 . 1 7 9}$ & $\mathbf{4 0 9 . 6 0 9}$ & $\mathbf{1 7 4 . 1 5 3 . 1 4 6}$ & $\mathbf{- 4}$ \\
2017 & 109.511 .390 & 83.533 .953 & 531.501 & 193.576 .844 & 11.2 \\
2018 & 112.758 .617 & 97.231 .289 & 200.039 & 210.189 .945 & 8.6 \\
\hline
\end{tabular}

Source: GDSAO (2019)

In the research period (2017-2018), there were 11 airlines operating licensed by the General Directorate of Civil Aviation (GDCA) in Turkey (Table 2). Of these, five airlines (Turkish Airlines, Pegasus Airlines, SunExpress, Onur Air, and AtlasGlobal) operate as scheduled; three non-scheduled (Corendon Airlines, Freebird Airlines, and Tailwind Airlines); and remaining three airlines (MNG Airlines, ULS Airlines Cargo, and Air ACT) operate as freight forwarders only. As seen in Table 2, Turkish Airlines as a flag carrier dominate both the domestic and international market with a $61 \%$ market share for each. Pegasus Airlines as a low-cost carrier has taken over $31 \%$ of domestic and $19 \%$ of the international market. SunExpress, a joint venture of Turkish Airlines and Lufthansa, possesses $5 \%$ of domestic and $8 \%$ of the international market. Onur Air and AtlasGlobal are privately-owned companies having small shares of the Turkish Airlines' market. While Corendon, Freebird, and Tailwind as charter airlines mostly operate in summer seasons to transport passengers internationally; they do not have operations in the domestic market. 
Table 2

Airlines licensed by GDCA

\begin{tabular}{|c|c|c|c|c|c|}
\hline Airlines & $\begin{array}{c}\text { Foundation } \\
\text { date }\end{array}$ & Fleet & $\begin{array}{l}\text { Operation } \\
\text { type }\end{array}$ & $\begin{array}{c}\text { Domestic } \\
\text { market share } \\
(2019)^{*}\end{array}$ & $\begin{array}{l}\text { International } \\
\text { market share } \\
\qquad(2019)^{*}\end{array}$ \\
\hline Turkish Airlines & 1933 & $\begin{array}{l}309 \text { (144 Boeing, } \\
165 \text { Airbus) }\end{array}$ & Scheduled & $61 \%$ & $61 \%$ \\
\hline SunExpress & 1989 & $46(\mathrm{~B} 737-800)$ & Scheduled & $5 \%$ & $8 \%$ \\
\hline Pegasus Airlines & 1990 & $\begin{array}{l}81 \text { (47 B737-800, } \\
34 \text { A320) }\end{array}$ & Scheduled & $31 \%$ & $19 \%$ \\
\hline Onur Air & 1992 & $\begin{array}{l}27 \text { (11 A330, } 8 \text { A321, } \\
8 \text { A320) }\end{array}$ & Scheduled & $1 \%$ & $3 \%$ \\
\hline MNG Airlines & 1997 & $6(5$ A300, 1 A330) & Cargo & - & - \\
\hline Freebird Airlines & 2000 & 7 (A320) & Charter & $0.01 \%$ & $1 \%$ \\
\hline AtlasGlobal & 2001 & $\begin{array}{l}16(1 \mathrm{~A} 319,4 \mathrm{~A} 320 \\
10 \mathrm{~A} 321,1 \mathrm{~A} 330)\end{array}$ & Scheduled & $1 \%$ & $3 \%$ \\
\hline ULS Airlines Cargo & 2004 & $3(\mathrm{~A} 310)$ & Cargo & - & - \\
\hline Corendon Airlines & 2004 & $\begin{array}{l}10(9 \text { B737-800, } \\
1 \text { B737-8 MAX) }\end{array}$ & Charter & 0.004 & $3 \%$ \\
\hline Air ACT & 2004 & $5(\mathrm{~B} 747-400)$ & Cargo & - & - \\
\hline Tailwind Airlines & 2006 & $5(\mathrm{~B} 737-400)$ & Charter & 0.003 & $1 \%$ \\
\hline
\end{tabular}

Note: * The market share data were retrieved from The Union of Chambers and Commodity Exchanges of Turkey (TOBB) (2020)

Source: GDCA (2019; retrieved 5 May 2019)

\section{METHODOLOGY}

In this study, a qualitative research method is used to investigate the competitive strategies of passenger carriers in the Air Operator Certificate (AOC) of Turkey, and the data were collected through in-depth interviews. For this purpose, a survey based on Porter's generic strategies and Miles and Snow's typology was developed by the authors and then adapted to the airline industry. The survey, including structured and semi-structured questions was used to collect data from airline managers individually interviewed. Qualitative data collection was preferred to collect first-hand data directly from the executives who are in strategic decisionmaking mechanisms of the respective firms. After a comprehensive review of the literature, 14 questions were included into the preliminary version of the interview form. Each structured question in the first part inquired about one of the features of the Miles and Snow's typology or Porter's generic strategies. By following questions, the competition structure of the Turkish air passenger transportation industry and the perception of the competition by top executives have been tried to be determined. 
The validity of the data collection tool is a big concern in all kinds of research designs. Hammersley (1987) defined the validity as "an account is valid or true if it represents those features of the phenomena accurately, that it is intended to describe, explain or theorise." Winter (2000) set forth two features of validity: first, whether the means of measurement are accurate, and secondly, whether they actually measure what they are intended to measure.

The survey has been prepared in four stages. First phase: 14 questions were prepared by using the original literature of Miles and Snow (1978) and Porter (1980, 1985). Second phase: for the validity, all the questions were checked thoroughly by subject-relevant faculty members in the field of management and aviation to secure consistency and accuracy, and necessary corrections were made. Third phase: experts on methodology, checked whether the structure and the content of the questions in terms of propriety and objectivity and the second phase corrections were made. Fourth phase: the pilot interviews were held with two executives from one of the airline companies at different times. Questions signalling ambiguities were tailored one more time and the survey was finalised.

The entire sample was included in the study, which are all private airline companies carrying passengers, licensed by the Turkish GDCA, namely SunExpress, Pegasus Airlines, Onur Air, AtlasGlobal, IZair, Corendon Airlines, Freebird Airlines, and Tailwind Airlines. The senior executives from these eight airlines (i.e., presidents or vice presidents of airline companies, senior managers in strategic planning, corporate planning, and trade and marketing departments) were reached via emails and phones, and appointments were taken. Thirteen executives from these airlines were interviewed between October 2017 and January 2018, in the headquarters (Istanbul, Izmir, and Antalya) of respective airlines. According to Boddy (2016), the question of what constitutes an appropriate sample size in qualitative research can only be answered within the context and the scientific paradigm of the research being conducted. The sample size was quite appropriate for data saturation to represent the Turkish airline market. These interviewees in their subject expertise are all who are relevant to this research topic. The interviews were audio-recorded and partially noted, and they lasted between 1 hour 30 minutes and 4 hours and 10 minutes.

Once the data collection has been completed, the interviews were transcribed. Interviews with more than one senior executive in the same airline company have been combined. The transcriptions were carefully studied and analysed. 


\section{FINDINGS}

This section includes findings on the strategic choices of the airlines competing in the Turkish passenger market. Based on Miles and Snow's typology, passenger airlines seem to demonstrate the features of analyser and/or defender approach. In general, the same airline companies carrying passengers also employ all of the Porter's competitive strategies together; however, cost leadership is at the forefront mostly.

The results of the structured interview are shown in Table 3. The table also includes the comparison of competitive approaches and strategies between scheduled and charter airlines while each airline's competition perception was put forward. The letters A, B, C, D, and $\mathrm{E}$ represent scheduled airline companies while the letters $\mathrm{X}, \mathrm{Y}$, and $\mathrm{Z}$ belong to charter airlines.

Analysis of Table 3 indicates that firms competing in the Turkish air transportation sector have analyser and/or defender approach according to Miles and Snow's typology.

In response to Question 2, "Which of the following statements best describe your business?" the response given by airlines A, C, D, and X support the prospector competition typology, which differs from the outcome competition strategy. The answers such as "We follow the change, we try to implement it, we support innovations and we have flexible behaviour," however illustrate that they are in the analyser and/or defender approaches.

The responses given to the first 12 questions positioning airline companies according to the Miles and Snow's competitive typology revealed that airline companies mainly adopted analyser and/or defender approaches, except Questions 2 and 9.

Question 13 inquires on Porter's generic competitive strategies. A and B firms implement all three generic strategies. Airline A's director declared that these generic strategies are prioritised, and they mostly have a competitive advantage by differentiation strategy producing different services (unlimited business campaign, free fly and bus services, transporting pets outside the cabin, etc.) in the sector. As for Airline B, although it implements all of the three strategies, the executives of Airline B have expressed that the firm's priority is a specific group of customers; that is why they continuously look for niche markets. Scheduled airline operators, $\mathrm{C}$ and $\mathrm{D}$, and charter Airline $\mathrm{X}$ have adopted cost reduction in their operations following Porter's generic strategy. As Airline E has adopted only the wet-lease 
business model since its establishment, its customer has been an airline operator and focused on a specific group of customers in a particular part of the market. Executives of charter Airline Y declared that they do not sacrifice quality while focusing on a specific segment of the market and the customer group so that costs can rise and reflect this in prices. When charter Airline $\mathrm{Z}$ examined, they are focusing on niche markets and specific customer groups by cost reduction. It can be generally deduced that all of Porter's generic strategies are used together, and the cost reduction comes to the forefront in the Turkish air passenger transportation sector. However, some exceptions exist like Airlines A and Y. Airline A has expressed that its competitors are not low-cost airlines and that they are rivalling the flag carrier with the strategy of differentiation. Charter Airline Y management also stated that they kept the quality service on the frontline before the cost and put the cost into the backwards.

Question 14 asked the managers to learn how competitive strategies are formulated in airline companies. Competition strategies in $\mathrm{E}, \mathrm{Y}$, and $\mathrm{Z}$ airlines are established by the board of directors $(\mathrm{BoD})$. In $\mathrm{A}, \mathrm{B}$, and $\mathrm{D}$ airlines, decisions are made by the $\mathrm{BoD}$, taking into account the previous period data, customer feedback, and behaviour of competitors. Airline $\mathrm{C}$ management has stated that it takes a position by following its competitors while forming competitive strategies. In Airline X company, competition strategies are formulated by the CEO or head of $\mathrm{BoD}$ so that responsibility belongs to only one person.

Table 4 shows the frequency distribution of the responses concerning Miles and Snow's competition typologies. In response to the questions asked, if there is an application other than the features listed by Miles and Snow, an option called "others" was created for the interviewees. This option was put there to leave an open door in order to see that the airlines might stay outside the Miles and Snow's typology. 


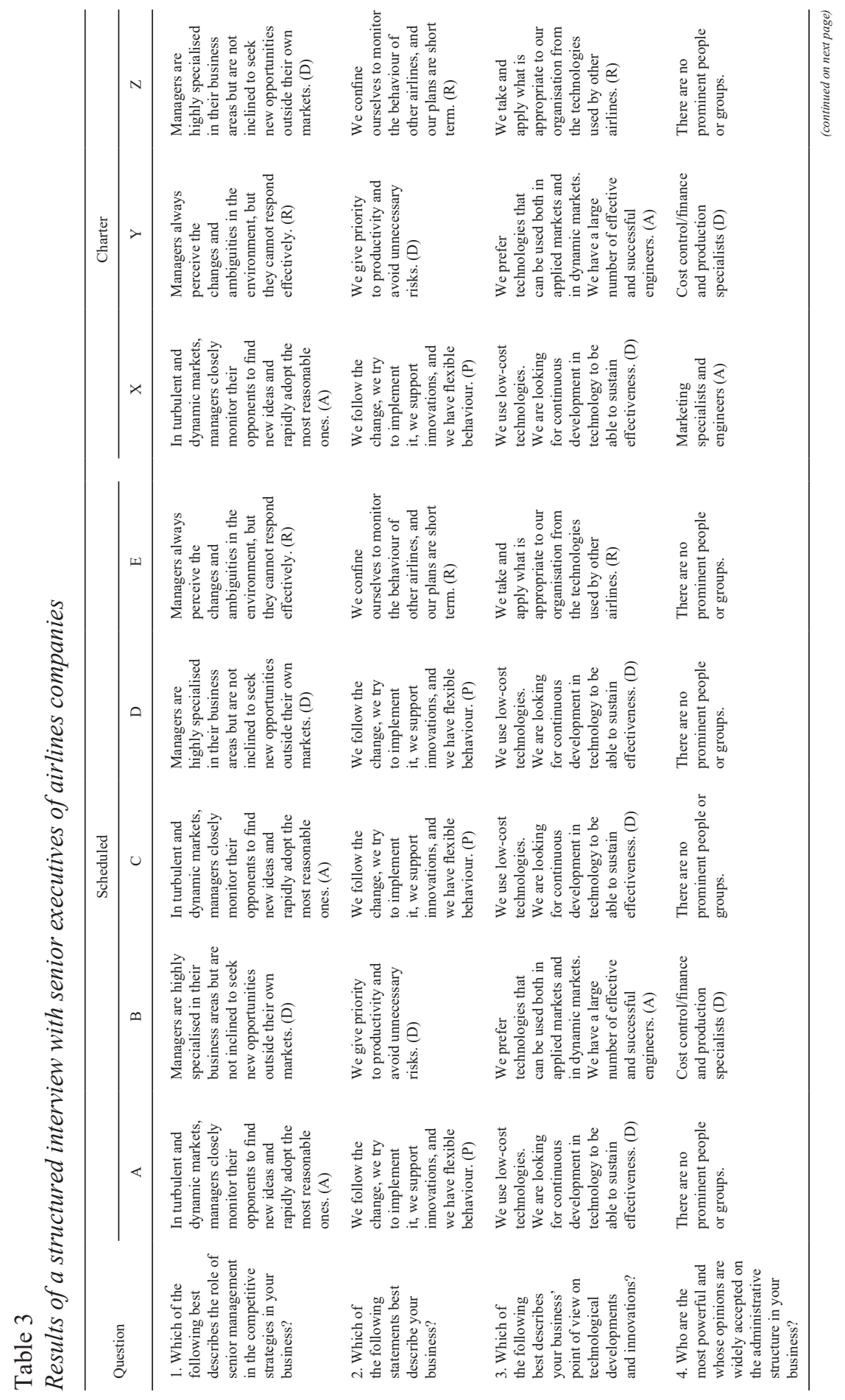




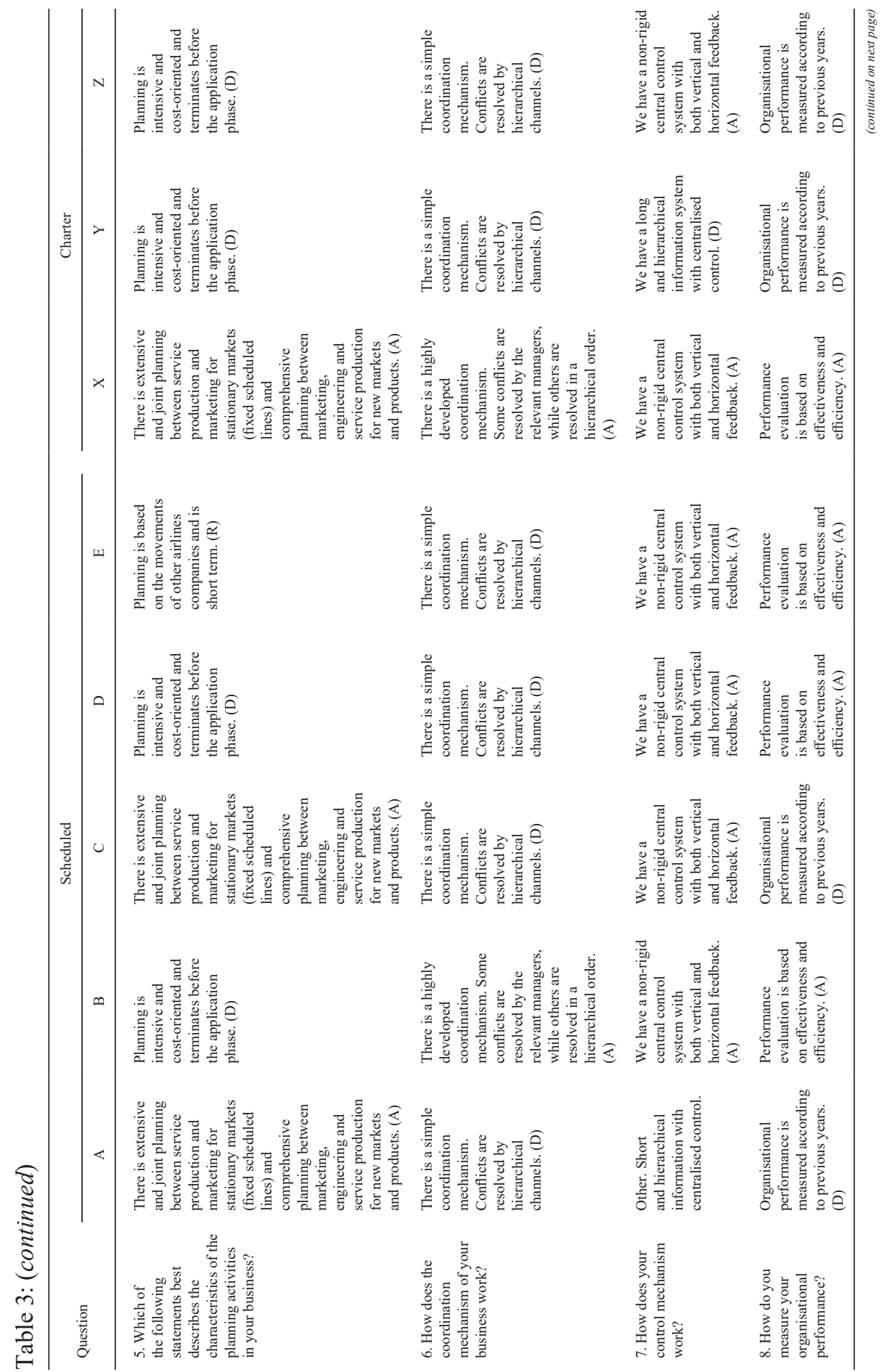




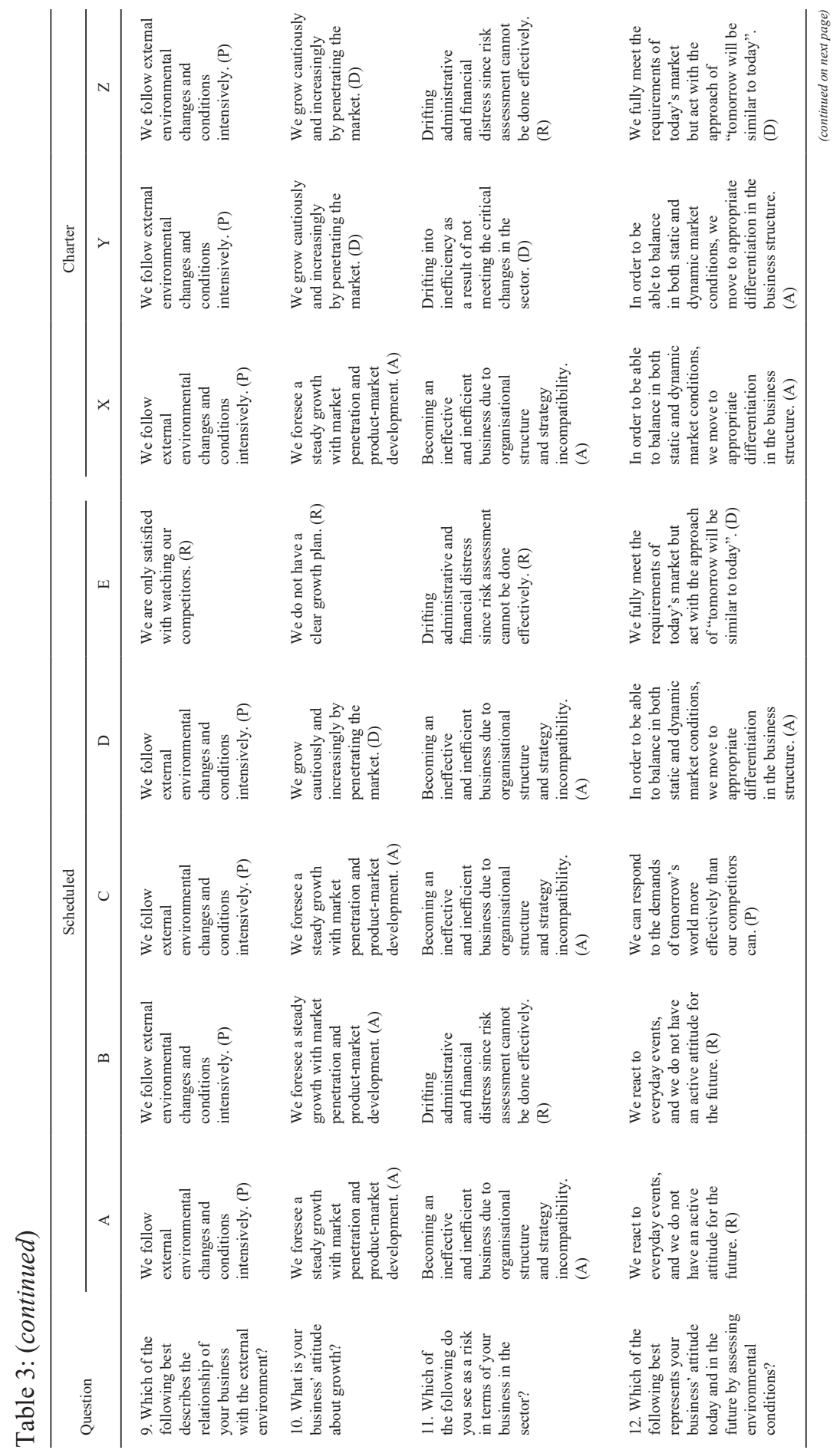




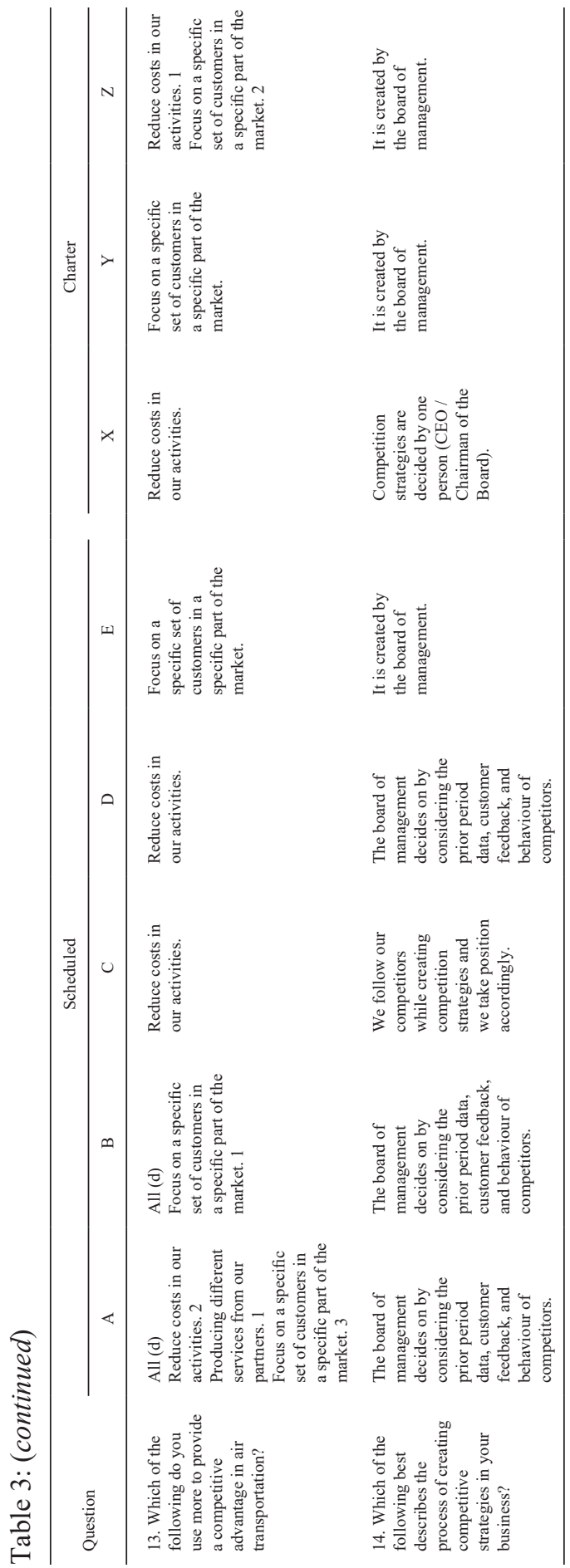


Table 4

Frequency distribution of airlines according to the Miles and Snow's competition typology

\begin{tabular}{lcccccccc}
\hline & A & B & C & D & E & X & Y & Z \\
\hline Prospectors (P) & 2 & 1 & 3 & 2 & - & 2 & 1 & 1 \\
Analysers (A) & 4 & 5 & 5 & 4 & 2 & 9 & 2 & 1 \\
Defenders (D) & 3 & 4 & 3 & 5 & 2 & 1 & 8 & 6 \\
Reactors (R) & 1 & 2 & - & - & 7 & - & 1 & 3 \\
Other & 2 & - & 1 & 1 & 1 & - & - & 1 \\
Dominant typology & A-D & A-D & A-(D+P) & D-A & R & A & D & D \\
\hline
\end{tabular}

From Table 4, it can be inferred that the scheduled passenger carriers predominantly adopt an analyser-defensive strategy of Miles and Snow's competitive typology. Airlines A and B primarily implement analyser and partly a defensive strategy while Airline D acts as a defender and partly an analyser. Airline $\mathrm{C}$ business also understands competition with an analyser approach, followed by an equal rate of defensive and prospective attitudes. Airline E follows a quite strict reactive strategy.

It seems that charter airline businesses reflect Miles and Snow's features more clearly than the scheduled ones. While Airline X has adopted analyser strategy, Airlines $\mathrm{Y}$ and $\mathrm{Z}$ are in a defender approach. The reason that Airline $\mathrm{X}$ operator is in analyser typology can be found in the explanations of the executives. Charter airline $\mathrm{X}$ has a target of $75 \%$ retail sales (seat only) in its 10-year vision of airline operations beyond being a charter airline in the aviation sector. At the same time, there are growth targets by increasing aircraft numbers every year. That is why Airline $\mathrm{X}$ has a different approach to the competition than the other two charters.

\section{DISCUSSION}

From the perspective of Miles and Snow's typology, it can be stated that the airlines operating in Turkey do not follow prospector competition strategies and do not reflect the pure characteristics of leading strategies. The main reason for not having a prospector strategy in the sector might be economic, political, and strategic factors related to the country. Factors such as Turkey's rapidly changing political landscape, security concerns, and persistence of regional uncertainty might have compelled the scheduled airlines to implement analyser-defender competitive approach rather than prospector. On the other hand, because of the flag carrier's dominant position in the sector, the other airlines might implement analyser-defender competitive approach involuntarily. 
This study included all private airlines except the flag carrier, Turkish Airlines. Torlak et al. (2011) identified Turkish Airlines as the most competitive company in the Turkish market regarding the critical success factors they have examined. The advantageous comparative position of Turkish Airlines seems to require other private airlines to move according to the leading airline's moves. Although Turkish Airlines' more than $50 \%$ shares are open to public, as a flag carrier of Turkey it might have some privileges over fully private companies. That all the senior executives of scheduled private airlines are in the view of that government protects and supports the flag carrier gives insight sufficiently. While only the executives of the leading airline of low-cost carrier model in Turkey state that in some cases they have adopted prospector strategy (even if this airline appears predominantly analyser and defender) which is partially inconsistent with the view of what Segev (1989) proposed, the other scheduled airlines overwhelmingly implement analyser and defender approaches. Only one scheduled airline implements reactive strategy by giving a different response from the others. The main reason is that $98.62 \%$ share of Airline E belongs to one of the other scheduled airlines; however, it has own identity and licensed by GDCA (2018) as a separate airline company.

Charter airlines were more stable than scheduled airlines in their competition to demonstrate pure strategies of Miles and Snow's typology. One of the charter airlines, which is to change its business model and aim the growth strategy within a 10 -year vision, emerged as implementing analyser approach. The other two charter airlines demonstrate all aspects of the defender approach due to their determination to maintain their existing structure as a stable.

It is claimed that while pure strategies protect the firm from rival's attacks (Miles et al., 1978), hybrid strategies are exposed to competition from both cost leadership and differentiation strategies (Tavalaei \& Santalo, 2019). According to Porter (1980), firms should apply either differentiation or cost leadership strategy; combining these two generic strategies leads to "stuck-in-the-middle" trap resulting in inferior performance. As Parnell and Hershey (2005) indicated, combination strategies might have inferior and superior impacts on performance of the companies. In this study, it is revealed that two airlines have been mostly applying a differentiation strategy and the quality is more important than the costs compared to the other airlines. Hence, the costs and prices of these airlines are higher than the others. Whether the airlines in the Turkish air transport market adopt the strategy of differentiation or the strategy of cost leadership, it is one of the conclusions that they continuously seek out niche routes and would like to fly to them primarily. Even though Thornhill and White (2007) show that implementing a pure strategy clarifies positioning, prevents confusion, and avoids mutually exclusive trade-offs; this research reveals the opposite that the hybrid strategies are applied by airline 
companies consciously or not. The results of this study support Heracleous and Wirtz (2009) claim that Singapore Airlines sustained its competitive advantage, through effectively implementing a dual strategy based on both differentiations through service excellence and innovation and cost leadership.

Contrary to Porter's idea of implementing more than one generic strategy will lead to "stuck in the middle" trap, some airline firms in Turkey declare that they apply all of the generic strategies, supporting Dostaler and Flouris (2006) results which indicate "integrated cost and differentiation strategy" (Coulter, 2002; Dostaler \& Flouris, 2006; Heracleous \& Wirtz, 2009). It is also supported by some other studies suggesting similar results. Anderson and Wang (1997) proposed a heterogeneous competitive strategy which is flexible, multidimensional and also necessary to gain and sustain competitive advantages over time. Shinkle et al. (2013) found that the benefits of a pure strategy were diminished when the institutional environment had a low degree of market orientation but were increased when the institutional environment was more market oriented.

Competition strategies in airline companies seem to have been formed by the $\mathrm{BoD}$ to a large extent. In some airlines, decisions taken by the $\mathrm{BoD}$ are based on previous period data, customer feedback, and behaviour of competitors. Even though these airlines are in the position of being the boss company, it is understood that competition decisions are taken by consulting in a $\mathrm{BoD}$. One of the executives said in the interview: "Until now we haven't had a goal like an opening to the public or so-called institutionalization (transition to more professional management in Turkish management literature) but now we know that it is inevitable, and we are taking steps towards institutionalization." Even that statement demonstrates that these airlines, even if they are boss companies, understand the importance of institutionalisation and that efforts and quests have been shown to systematise the strategic management process.

\section{CONCLUSION}

This study was designed to determine the competitive approaches of licensed private airlines in Turkish passenger market comprehensively. The scheduled airline companies of Turkey were mostly revealed to adopt hybrid analyserdefender competition strategies, whereas charter airlines were closer to demonstrate Miles and Snow's pure strategies. The scheduled airlines do not show the features of one pure Miles and Snow's strategy. This research revealed that an airline company might implement hybrid strategies like analyser- 
defender. It can also be concluded that the private airlines carrying passengers in Turkish transportation sector implement all of Porter's generic competitive strategies simultaneously; however, mainly cost leadership comes to the forefront. Implementing hybrid strategies might offer more strategic options and provide flexibility at the turbulent environment of the airlines.

After all, combining Porter's generic strategies and Miles and Snow's typology seems viable and the airline companies operating in Turkey incorporated pure strategies simultaneously. The airlines, applying pure cost leadership and "integrated cost and differentiation strategy," matched with analyser-defender strategies. In this research, the airlines converge where cost leadership and differentiation meet since the executives mind the costs and innovation simultaneously, most notably for the fragile aviation industry.

With this study, strategic orientation and competitive strategies of the firms in the Turkish airline industry, which are determined and/or enforced by the BoD or senior executives, are set forth for the first time in Turkey. It is believed that this study will fill an important gap in the relevant literature. The study contributes to the relevant literature in several ways. First, it presents several examples of co-existence of generic strategies implemented at the same time by a single firm. Second, this study provides instances where both typologies are employed by the same firm. As stated by researchers, Porter's framework overlaps with Miles and Snow's typologies. In this research, two airline companies leading the differentiation strategy matched with Miles and Snow's analyser strategy instead of prospector. And lastly, since it is tested the classical managerial typologies in an emerging economy, the study will give insights for emerging air transport markets which recently meet inter-firm competition.

Since most of the executives of the airlines indicated that they did not apply the formal strategic management/planning processes, this study also shows the institutionalisation need for the industry. Thus, this study shows the urgent precautions for the institutionalisation for the managers of both the potential businesses that may enter the sector, and those at present. The results also prove that regulatory agencies need to revise market conditions in Turkey to support healthy competition.

The main limitation of this study is that it was based on the opinions of the executives. Therefore, it omitted some critical aspects of airline competition such as airlines' market shares, product quality, customer loyalty, customer service, etc. 
The results of the study are based on the research period. In the future, considering factors such as population growth, disposable income growth, economic and tourism growth, stability expectations, the additional capacity of the new Istanbul airport, potential more liberal bilateral/multilateral agreements, and unforeseen domestic and international crises, etc., new domestic and foreign players may be able to join the market or leave the market. This might change all strategic orientations and behaviours of the airline companies. This study aimed to apply two classical strategy frameworks; however, future studies might apply different management theories such as resource-based view and dynamic capabilities perspective. Also, the performance variables either inferior or superior might be associated with the combination of these strategies. Besides, whether Miles and Snow's typology might match differently with Porter's generic strategies in different industries or not, it can also be the future research topic.

\section{REFERENCES}

Aldemir, H. Ö., \& Kuyucak Şengür, F. (2017). Academic foundations of air transportation research in an emerging country: A bibliometric analysis. International Journal of Aviation Systems, Operations and Training, 4(1), 15-27. https://doi.org/10 .4018/IJASOT.2017010102

Allen, R. S., \& Helms, M. M. (2006). Linking strategic practices and organizational performance to Porter's generic strategies. Business Process Management Journal, 12, 433-454. https://doi.org/10.1108/14637150610678069

Anderson, D., \& Wang, J. (1997). A heterogeneous competitive strategy: Implementation and implications. International Journal of Business, 2(1), 69-81.

Anwar J., \& Hasnu, S. A. F. (2017). Strategy-performance relationships: A comparative analysis of pure, hybrid, and reactor strategies. Journal of Advances in Management Research, 14(4), 446-465. https://doi.org/10.1108/JAMR-07-2016 $-0056$

Anwar, J., Shah, S., \& Hasnu, S. (2016). Business strategy and organizational performance: Measures and relationships. Pakistan Economic and Social Review, 54(1), 97122.

Avci, U., Madanoglu, M., \& Okumus, F. (2011). Strategic orientation and performance of tourism firms: Evidence from a developing country. Tourism Management, 32(1), 147-157. https://doi.org/10.1016/j.tourman.2010.01.017

Bahaee, M. S. (1992). Strategy-comprehensiveness fit and performance. Australian Journal of Management, 17(2), 195-215. https://doi.org/10.1177/0312896293 01700202

Beekun, R. I., \& Ginn, G. O. (1993). Business strategy and interorganizational linkages within the acute care hospital industry: An expansion of the Miles and Snow's typology. Human Relations, 46(11), 1291-1318. https://doi.org/ $10.1177 / 001872679304601102$ 
Boddy, C. R. (2016). Sample size for qualitative research. Qualitative Market Research, 19(4), 426-432. https://doi.org/10.1108/QMR-06-2016-0053

Brunk, S. E. (2003). From theory to practice: Applying Miles and Snow's ideas to understand and improve firm performance. Academy of Management Executive, 17(4), 105-108. https://doi.org/10.5465/ame.2003.11851877

Bustamam, U. S. A., \& Pech, R. (2016). An examination of Malay business growth strategies using Miles and Snow's strategic typology. Scientific Cooperations 2nd International Conference on Social Sciences, Istanbul-Turkey, 2-3 April 2016. Unpublished conference paper.

Cassol, A., Cintra, R. F., Riberio, I., Oliveira, A. C., \& Lorandi, B. (2019). Measurement of the strategic behavior of micro and small-sized enterprises: An analysis supported by the Miles and Snow typology (1978). Revista do Mestrado em Administração e Desenvolvimento Emprsial Universidade Estácio de Sá - Rio de Janeiro, 23(1), $105-125$.

Chaffee, E. E. (1985). Three models of strategy. Academy of Management Review, 10(1), $89-98$.

Coulter, M. K. (2002). Strategic management in action (2nd ed.). Upper Saddle River, NJ: Prentice Hall.

Cronshaw, M., Davis, E., \& Kay, J. (1994). On being stuck in the middle or good food costs less at Sainsbury's. British Journal of Management, 5(1), 19-32.

DeSarbo, W. S., Di Benedetto, C. A., Song, M., \& Sinha, I. (2005). Revisiting the Miles and Snow strategic framework: Uncovering interrelationships between strategic types, capabilities, environmental uncertainty, and firm performance. Strategic Management Journal, 26(1), 47-74.

Dostaler, I., \& Flouris, T. (2006). Stuck in the middle revisited: The case of the airline industry. Journal of Aviation/Aerospace Education \& Research, 15(2), 33-45.

Gabrielsson, M., Seppala, T., \& Gabrielsson, P. (2016). Realizing a hybrid competitive strategy and achieving superior financial performance while internationalizing in the high-technology market. Industrial Marketing Management, 54, 141-153.

GDCA (General Directorate of Civil Aviation). (2018). Retrieved 20 February 2018 from http://web.shgm.gov.tr/tr/havacilik-isletmeleri/2063-hava-tasima-isletmeleri

GDCA. (2019). Havayolu İşletmeleri. Retrieved 05 May 2019 from http://web.shgm .gov.tr/tr/havacilik-isletmeleri/2063-hava-tasima-isletmeleri

GDSAO (General Directorate of State Airport Operations). (2019). Havalimanları Karşılaştırmalı İstatistikleri. Retrieved 12 June 2019 from http://www.dhmi .gov.tr/istatistik.aspx

Gibcus, P., \& Kemp, R. G. M. (2003). Strategy and small firm performance. Research report H200208, SCALES Scientific Analysis of Entrepreneurship and SMEs, Zoetermeer. Netherlands: Zoetermeer (EIM, Business \& Policy Research).

Gimenez, F. A. P. (1999). Miles and Snow's strategy model in the context of small firms. Proceedings of the 1999 ICSB Naples Conference, June 20-23, 1999, Naples, Italy.

Goll, I., Johnson, N. B., \& Rasheed, A. A. (2006). Strategic responses to deregulation and their performance implications in the U.S. airline industry. Business and Politics, $8(2), 1-37$. 
Hambrick, D. C. (1983). Some tests of the effectiveness and functional attributes of Miles and Snow's strategic types. Academy of Management Journal, 26(1), 5-26.

Hammersley, M. (1987). Some notes on the terms 'validity' and 'reliability'. British Educational Research Journal, 13(1), 73-81.

Hani, A., Hossein, S. M., \& Hassan, D. F. (2020). Conceptual typology of project strategy based on business environment contingency in Iran petrochemical industry projects. Productivity Management (Beyond Management), 13(51), 19-44.

Hawrysz, L. (2020). Strategic orientation and effects of e-administration: Findings from the Miles and Snow framework. Administrative Sciences, 10(2), 35, 1-18.

Helmig, B., Hinz, V., \& Ingerfurth, S. (2014). Extending Miles \& Snow’s strategy choice typology to the German hospital sector. Health Policy, 118(3), 363-376.

Heracleous, L., \& Wirtz, J. (2009). Strategy and organisation at Singapore Airlines: Achieving sustainable advantage through dual strategy. Journal of Air Transport Management, 15, 274-279.

Hitt, M. A., Ireland, R. D., \& Hoskisson, R. E. (2003). Strategic management: Competitiveness and globalization (5th ed.). Ohio: Thomson South-Western.

Hotel Association of Turkey. (2019). Havalimanı İstatistikleri. Retrieved 30 August 2019 from http:/www.turob.com/tr/istatistikler?text=\&Month=1\&Year=2019

IATA (International Air Transport Association). (2017, October 24). 2036 forecast reveals air passengers will nearly double to 7.8 billion. Retrieved 4 July 2019 from http://www.iata.org/pressroom/pr/Pages/2017-10-24-01.aspx

IATA. (2018a). Fact sheet: Economic and social benefits of air transport. Retrieved 10 July 2019 from https://www.iata.org/pressroom/facts_figures/fact_sheets/Documents/ fact-sheet-economic-and-social-benefits-of-air-transport.pdf

IATA. (2018b). IATA members. Retrieved 1 November 2019 from https://www.iata .org/about/members/Pages/index.aspx

ICAO (International Civil Aviation Organization). (2017). 2018 annual report. Retrieved 4 July 2019 from https://www.icao.int/annual-report-2017/Pages/the-world-of-air -transport-in-2017.aspx

James, W. L., \& Hatten, K. J. (1995). Further evidence on the validity of the self-typing paragraph approach: Miles and Snow strategic archetypes in banking. Strategic Management Journal, 16(2), 161-168.

Johnson, N. B., Sambharya, R. B., \& Bobko, P. (1989). Deregulation, business strategy, and wages in the airline industry. Industrial Relations, 28(3), 419-430.

Jusoh, R., \& Parnell, J. A. (2008). Competitive strategy and performance measurement in the Malaysian context: An exploratory study. Management Decision, 46(1), 5-31.

Karingithi, M. G., Aosa, E., Ogollah, K., \& Njihia, J. (2020). Influence of strategy typology on performance of freight forwarding companies in Kenya. DBA Africa Management Review, 10(1), 28-36.

Khadaroo, J., \& Seetanah, B. (2008). The role of transport infrastructure in international tourism development: A gravity model approach. Tourism Management, 29(5), 831-840.

Kling, J. A., \& Smith, K. A. (1995). Identifying strategic groups in the US airline industry: An application of the Porter model. Transportation Journal, 35(2), 26-34. 
Köseoglu, M. A., Topaloglu, C., Parnell, J. A., \& Lester, D. L. (2013). Linkages among business strategy, uncertainty and performance in the hospitality industry: Evidence from an emerging economy. International Journal of Hospitality Management, 34, 81-91.

Lauer, T. (2019). Generic strategies, outpacing and blue ocean: Discussing the validity of three strategic management theories using case studies from airlines and grocery retail. Club of Economics in Miskolc TMP, 15(1), 57-66.

Lin, C., Chiu, Y. W., Chen, W. C., \& Ting S. F. (2020). Exploring differences in competitive performance based on Miles and Snow's strategy typology for the semiconductor industry. Industrial Management \& Data Systems, 120(6), 1125-1148.

Manev, I. M., Manolova, T. S., Harkins, J. A., \& Gyoshev, B. S. (2015). Are pure or hybrid strategies right for new ventures in transition economies? International Small Business Journal, 33(8), 951-973.

Manu, F. A., \& Sriram, V. (1996). Innovation, marketing strategy, environment, and performance. Journal of Business Research, 35(1), 79-91.

Martins, T. S., Kato, H. T., Martins R. R., \& da Silva E. D. (2014). An analytical framework for Miles and Snow typology and dynamic capabilities. Revista Ibero - Americana de Estratégia, 13(1), 22-33.

McDaniel, S. W., \& Kolari, J. W. (1987). Marketing strategy implications of the Miles and Snow strategic typology. Journal of Marketing, 51(4), 19-30.

Miles, R. E., \& Snow, C. C. (1978). Organizational strategy, structure, and process. New York: McGraw-Hill.

Miles, R. E., Snow, C. C., Meyer, A. D., \& Coleman Jr., H. J. (1978). Organizational strategy, structure, and process. The Academy of Management Review, 3(3), 546562.

Moore, M. (2005). Towards a confirmatory model of retail strategy types: An empirical test of Miles and Snow. Journal of Business Research, 58(5), 696-704.

Morgan, R. E., \& Strong, C. A. (2003). Business performance and dimensions of strategic orientation. Journal of Business Research, 56, 163-176.

O’Regan, N., \& Ghobadian, A. (2006). Perceptions of generic strategies of small and medium sized engineering and electronics manufacturers in the UK: The applicability of the Miles and Snow typology. Journal of Manufacturing Technology Management, 17(5), 603-620.

Obel, B., \& Gurkov, I. B. (2013). Revisiting Miles-Snow typology of strategic orientation using stakeholder theory. ICOA Working Papers Series, 2013-02, Aarhus University, Business and Social Sciences, Interdisciplinary Center for Organizational Structure.

Omwoyo, R. M. (2016). Effects of generic strategies on the competitive advantage of firms in Kenya's airline industry: A survey of selected airlines. Master's thesis, United States International University Africa.

Parnell, J. A., \& Hershey, L. (2005). The strategy-performance relationship revisited: The blessing and the curse of the combination strategy. International Journal of Commerce and Management, 15(1), 17-33. 
Parnell, J. A., \& Wright, P. (1993). Generic strategy and performance: An empirical test of the Miles and Snow typology. British Journal of Management, 4(1), 29-36.

Porter, M. E. (1980). Competitive strategy. New York: Free Press.

Porter, M. E. (1985). Competitive advantage: Creating and sustaining superior performance. New York: Free Press.

Segev, E. (1989). A systematic comparative analysis and synthesis of two business-level strategic typologies. Strategic Management Journal, 10(5), 487-505.

Şengür, F., \& Ustaömer, T. C. (2019). Türk havayolu sektörünün uluslararası rekabetçilik analizi. Anemon Muş Alparslan Üniversitesi Sosyal Bilimler Dergisi, 7(6), 211218.

Shinkle, G. A., Kriauciunas, A. P., \& Hundley, G. (2013). Why pure strategies may be wrong for transition economy firms. Strategic Management Journal, 34(10), 1244-1254.

Slater, S. F., \& Narver, J. C. (1993). Product-market strategy and performance: An analysis of the Miles and Snow strategy types. European Journal of Marketing, 27(10), $33-51$.

Smith, K. G., Guthrie, J. P., \& Chen M. J. (1986). Miles and Snow's typology of strategy, organizational size and organizational performance. Academy of Management, 1 , 45-49.

Sonmez, R., \& Eroglu, U. (2017). Firmalar arası rekabetçi etkileşim: Rekabetçi hamlelerin özellikleri ve misilleme arasındaki ilişki. Journal of Management Research, 13, 41-69.

Tavalaei, M. M., \& Santalo, J. (2019). Pure versus hybrid competitive strategies in the airport industry. Transportation Research Part A, 124, 444-455.

The World Bank (2019). Overview country context: Turkey. Retrieved 28 August 2020 from http://www.worldbank.org/tr/country/turkey/overview

Thornhill, S., \& White, R. E. (2007). Strategic purity: A multi-industry evaluation of pure vs. hybrid business strategies. Strategic Management Journal, 28(5), 553-561.

TOBB (The Union of Chambers and Commodity Exchanges of Turkey). (2020). 2020 report of The Union of Chambers and Commodity Exchanges of Turkey, Civil Aviation Assembly. Ankara, Turkey: TOBB.

Torlak, G., Sevkli, M., Sanal, M., \& Zaim, S. (2011). Analyzing business competition by using fuzzy TOPSIS method: An example of Turkish domestic airline industry. Expert Systems with Applications, 38, 3396-3406.

Weisenfeld-Schenk, U. (1994). Technology strategies and the Miles and Snow typology: A study of the biotechnology industries. $R \& D$ Management, 24(1), 57-64.

Winter, G. (2000). A comparative discussion of the notion of 'validity' in qualitative and quantitative research. The Qualitative Report, 4(3), 1-14.

Zahra, S. A., \& Pearce II, J. A. (1990). Research evidence on the Miles-Snow typology. Journal of Management, 16(4), 751-768. 